$$
\text { Љубомир Поповић }
$$

\title{
ВУКОВ ПРИСТУП ВЕРНАКУЛАРИЗАЦИЈИ И СТАНДАРДИЗАЦИЈИ КЊИЖЕВНОГ ЈЕЗИКА И ПРАВОПИСА КОД СРБА
}

\section{1. Увод}

Циљ овога рада је да укратко размотри следеће аспекте вернакуларизације (=понарођивања) и стандардизације књижевног језика, писма и правописа код Срба везане за Вукову реформу: најпре, Копитарову концепцију књижевног језика и његове идеје о решавању српског књижевнојезичког питања, као и на Копитаровим схватањима заснован Вуков програм књижевнојезичке и правописне реформе (тачка 2); затим, структуру и реализацију Вукове реформе, укључујући модификације и допуне почетног Копитар-Вуковог реформног програма (т. 3); и најзад, посебан начин на који је Вук створио књижевнојезички стандард за Србе (т. 4).

\section{2. Копитарови и Вукови ставови о књижевном језикуำ}

Копитарово интересоваюе за народну културу и за проблеме књижевног језика. - Познато је да се Копитар - добрим делом под утицајем Хердерових идеја - занимао за народник језик, за народне песме и друге умотворине, за обичаје и веровања, једном речи за народну културу словенских народа и народа југоисточне Европе, укључујући и Србе. При

1 У приказу Копитарових ставова, поред Копитарових текстова штампаних у Копитар 1984, коришћени су нарочито радови В. Јагића (1910: 185-214), љ. Стојановића (1924: 33-39), А. Белића (1948: 198-203), Р. Ленчека (1971 и 1983), Ј. Погачника (1977) и П. Ивића (1981). Вукови идеолошки ставови су изложени на основу Поповић 1988. 
том је Копитарово настојање да подстакне скупљање и презентирање оваквих знања требало да допринесе не само развоју тадашње филологије него и својеврсној културној афирмацији ових народа. А у тесној вези с тим интересовањима било је и Копитарево интересовање за решавање њихових књижевнојезичких и правописних проблема. За Вукову реформу је посебно важно да је Копитаров програм за овакву етничку културну и језичку афирмацију подразумевао скупљање народних песама и израду граматике и речника народног језика, уз захтев да се све то уради у етнографском духу, дескриптивно, без интервенције граматичара и лексикографа односно записивача. А додатна компонента Копитаровог програма било је и превођење Светог писма на народни језик. Једном речи, Копитар је имао своју концепцију књижевног језика и одговарајућег писма и начина на који треба створити односно реформисати књижевни језик. Зато он није само подстакао Вука да се бави народним језиком и фолклором него и да се ухвати у коштац са књижевнојезичким и правописним питањем код Срба, и при том га је усмерио у праву одређених решења.

Интерпретаиија Копитарових и Вукових ставова. - Да би се уочила веза Вуковог реформног програма са Копитаровим схватањима, у следећој табели дата је сажета интерпретација Копитарових и Вукових ставова, систематисана с обзиром на четири компоненте типичног идеолошког реформног програма. Те компоненте су: (1) књижевнојезичко и правописно опредељење, тј. општи ставови о пожељној природи књижевног језика и правописа (укључујући и писмо); (2) критика текуће ситуације (у светлу књижевнојезичког и правописног опредељења); (3) идејно решење текућег проблема, изнето као подстицај за неодложну акцију одговарајућег сегмента друштва одн. нације; и (4) операционализација тог решења, тј. конкретне мере које треба предузети да се решење реализује. 


\section{Копитарови и Вукови ставови}

(СРП = Копитарови ставови у вези са српском ситуацијом)

\begin{tabular}{|c|c|}
\hline $\begin{array}{c}\text { КОПИТАРОВА КОНЦЕПЦИЈА КЫИ- } \\
\text { ЖЕВНОГ ЈЕЗИКА }\end{array}$ & $\begin{array}{l}\text { ВУКОВ РЕФОРМНИ } \\
\text { ПРОГРАМ }\end{array}$ \\
\hline \multicolumn{2}{|c|}{ КЊИЖЕВНОЈЕЗИЧКО ОПРЕДЕЉЕЊЕ } \\
\hline \multicolumn{2}{|c|}{ Број књижевних језика (изван црквене употребе) } \\
\hline $\begin{array}{l}\text { Копитар је сматрао да треба да постоји } \\
\text { само један књижевни језик (изузимајући } \\
\text { језик цркве). }\end{array}$ & Вук је потпуно усвојио Копитаров став. \\
\hline \multicolumn{2}{|c|}{ Етничка природа књижевног језика } \\
\hline $\begin{array}{l}\text { Копитар је био за то да се као књижев- } \\
\text { ни језик употребљава говорни народни } \\
\text { језик. СРП: Копитар је одредио границе } \\
\text { „српског” народа }{ }^{2}\end{array}$ & $\begin{array}{l}\text { Треба писати говорним (=живим) } \\
\text { српским језиком. Српски књижевни је- } \\
\text { зик треба да буде заједнички за све који } \\
\text { говоре српским језиком, без обзира на } \\
\text { верску припадност (= принцип коек- } \\
\text { стензивности књижевног и народног је- } \\
\text { зика). }\end{array}$ \\
\hline \multicolumn{2}{|c|}{ Природа понарођеног књижевног језика и његов однос према ученом језику } \\
\hline $\begin{array}{l}\text { Треба писати на аутентичном народном је- } \\
\text { зику. Језици се не смеју мешати, односно не } \\
\text { сме се стварати „макаронски језик”. }\end{array}$ & $\begin{array}{l}\text { Треба писати аутентичним (= правим, чи- } \\
\text { стим и непоквареним) српским језиком. } \\
\text { Тај језик треба да буде потпуно одвојен од } \\
\text { ученог („славенског” одн. рускословенског), } \\
\text { који остаје само језик цркве. }\end{array}$ \\
\hline \multicolumn{2}{|c|}{ Писана форма књижевног језика } \\
\hline $\begin{array}{l}\text { Књижевни језик треба да буде писан } \\
\text { рационалном азбуком, на основу Аде- } \\
\text { лунговог принципа „пиши као што го- } \\
\text { вориш” (уп. Стојановић 1924: } 34-35) \text {. Ко- } \\
\text { питар је такође био против тога да неко } \\
\text { учено друштво одређује правопис (уп. } \\
\text { Копитар 1984: 152). СРП: Копитар је под- } \\
\text { ржавао Мркаљеву реформу (уп. Копитар } \\
\text { 1984: 142). }\end{array}$ & $\begin{array}{l}\text { Српски књижевни језик треба да има ау- } \\
\text { тентичну писану форму. }\end{array}$ \\
\hline
\end{tabular}

2 1815. Копитар каже: Србима - то је исправнији назив - називамо такозване Илирце, једну словенску грану народа која броји око пет милиона душа, простирући се од граница Крања, јужно од Купе и Саве све доле до Балканског масива, и од Јадранског мора до бугарског Тимока, при чему тај народ још има своје насеобине у Славонији и јужној Мађарској све до Сент Андреје код Будима (Копитар 1984: 165-166; а в. и стр. 186). 


\begin{tabular}{|c|c|}
\hline \multicolumn{2}{|c|}{ 2. КРИТИКА ТЕКУЋЕ СИТУАЦИЈЕ КОД СРБА } \\
\hline \multicolumn{2}{|c|}{ Књижевнојезичка ситуација } \\
\hline $\begin{array}{l}\text { СРП: Копитар је био против употребе } \\
\text { мешаног књижевног језика тј. славено- } \\
\text { српског. (Али је истицао значај Доситеја, } \\
\text { који је тражио да се пише само на народ- } \\
\text { ном језику.) }\end{array}$ & $\begin{array}{l}\text { По Вуковом мишљењу, писци (укључујући } \\
\text { и Доситеја), већином рођени у граду и } \\
\text { школовани на страним језицима, не знају } \\
\text { прави народни језик, пишу исквареним } \\
\text { језиком, а поједини (пре свега Видаковић) } \\
\text { стварају нови, хибридни језик („славе- } \\
\text { но-српски”) и немају никаквих правила } \\
\text { (пишу „по правилима баба-Смиљане”) }\end{array}$ \\
\hline \multicolumn{2}{|c|}{ Алфабетско-правописна ситуација } \\
\hline $\begin{array}{l}\text { СРП: Српску ћирилицу треба реформи- } \\
\text { сати. }\end{array}$ & $\begin{array}{l}\text { Азбука и правопис не одговарају народ- } \\
\text { ном језику. Писци пишу неуједначено, } \\
\text { чак и кад се ради о индивидуалном узусу. }\end{array}$ \\
\hline \multicolumn{2}{|c|}{ 3. РЕШЕЊЕ КЊИЖЕВНОЈЕЗИЧКОГ ПРОБЛЕМА } \\
\hline \multicolumn{2}{|c|}{ Књижевни језик } \\
\hline $\begin{array}{l}\text { Књижевни језик треба да се заснива на } \\
\text { језику села (због искварености градског } \\
\text { језика у додиру са страном цивилиза- } \\
\text { цијом). }\end{array}$ & $\begin{array}{l}\text { Књижевници треба да науче прави на- } \\
\text { родни језик и пишу њиме, и то сваки } \\
\text { књижевник на устаљен начин. Тај прави } \\
\text { народни језик је говорни језик Срба који } \\
\text { живе по селима далеко од градова. }\end{array}$ \\
\hline \multicolumn{2}{|c|}{ Писмо, графија и правопис } \\
\hline $\begin{array}{l}\text { У вези с азбуком треба применити наче- } \\
\text { ло „Пиши као што говориш”. Што се тиче } \\
\text { правописа, по Јагићу (1910: 195), Копи- } \\
\text { тар је (и ту се угледајући на старе Грке) } \\
\text { сугерисао Вуку тзв. фонетски правопис; } \\
\text { а по Љ. Стојановићу (1924: 35) Копитар је } \\
\text { у почетку био за тзв. етимолошки, а кас- } \\
\text { није је, радећи са Вуком, прихватио чист } \\
\text { фонетски правопис. }\end{array}$ & $\begin{array}{l}\text { Писмо, графију и правопис треба рефор- } \\
\text { мисати у складу с принципом „пиши као } \\
\text { што говориш” (што је подразумевало и } \\
\text { тзв. фонетски правопис), а књижевници } \\
\text { треба да пишу на конзистентан начин. }\end{array}$ \\
\hline
\end{tabular}




\begin{tabular}{|c|c|}
\hline \multicolumn{2}{|c|}{ 4. ОПЕРАЦИОНАЛИЗАЦИЈА РЕШЕЊА } \\
\hline \multicolumn{2}{|c|}{ Дијалекатска унифицикација } \\
\hline $\begin{array}{l}\text { Ослањајући се на модел формирања ста- } \\
\text { рограчког коинеа, Копитар је сматрао да } \\
\text { сви дијалекти заслужују да уђу у књижев- } \\
\text { ни језик односно да у почетку сваки пи- } \\
\text { сац треба да пише својим дијалектом, а } \\
\text { заједничка норма ће се постепено искри- } \\
\text { сталисати (уп. Стојановић 1924: 33, Лен- } \\
\text { чек } 1971 \text { и 1983: 127-131)3. СРП: Копитар } \\
\text { је преферирао ијекавски дијалекат. }\end{array}$ & $\begin{array}{l}\text { Сваки писац треба да пише својим дија- } \\
\text { лектом, што ће омогућити да се боље } \\
\text { упозна народни говор. (Сам Вук пише } \\
\text { својим завичајним говором - тршићким, } \\
\text { што значи ијекавски.) }\end{array}$ \\
\hline \multicolumn{2}{|c|}{ Стварање књижевнојезичког корпуса } \\
\hline $\begin{array}{l}\text { Треба скупљати и објављивати народне } \\
\text { песме (и друге умотворине), које егзем- } \\
\text { плификују аутентични народни језик. } \\
\text { Потребан је и превод Светог писма, који } \\
\text { представља доказ да је дати језик спосо- } \\
\text { бан да буде књижевни језик. }\end{array}$ & $\begin{array}{l}\text { Вук је такође сматрао да је потребно } \\
\text { скупљати и објављивати народне песме и } \\
\text { превести Нови завет. }\end{array}$ \\
\hline \multicolumn{2}{|c|}{ Лингвистички приказ народног језика } \\
\hline $\begin{array}{l}\text { Граматичари и лексикографи треба да } \\
\text { верно прикажу стварно стање говорног } \\
\text { језика, а не да прописују и исправљају } \\
\text { народни језик, тј. не смеју да интервени- } \\
\text { шу у складу са оним што мисле да треба } \\
\text { да буде. СРП: Тражио је да се изради гра- } \\
\text { матика и речник српског језика. Упући- } \\
\text { вао је Вука да се служи речницима које } \\
\text { су саставили „Шокци” („римокатолички } \\
\text { Срби”), а у другим словенским речници- } \\
\text { ма (уп. Копитар 1984: 160-161). А уред- } \\
\text { ницима Србских новина препоручивао } \\
\text { је граматике „српског” језика писане ла- } \\
\text { тиницом (уп. Копитар 1984: 146). }\end{array}$ & $\begin{array}{l}\text { Да би писци научили прави народни је- } \\
\text { зик, потребно је саставити граматику и } \\
\text { речник народног језика, у којима ће се } \\
\text { верно приказати аутентични народни } \\
\text { језик одн. показати његово лексичко бо- } \\
\text { гатство. }\end{array}$ \\
\hline Елаборација ново & књижевног језика \\
\hline
\end{tabular}

${ }^{3}$ Јагић (1910: 381) критикује такву концепцију и супротставља јој став Добровског. 
СРП: Копитар је био свестан проблема које доноси употреба народног језика као писаног (уп. Копитар 1984: 141). Али је мислио да ће се терминологија формирати касније, са развитком науке, и то на бази народног језика (уп. Копитар 1984: 203). Што се тиче старословенског језика, учени људи ће га изучавати и користити „богату ризницу за изучавање и чак обогаћивање свог матерњег језика" (уп. Копитар 1984: 147). Речи позајмљене из страних језика, укључујући и старословенски, треба посрбљавати (уп. Копитар 1984: 145).
Вук је признавао да књижевни језик не може бити без страних речи, али је сматрао да народни језик углавном задовољава потребе писаног изражавања.

\section{Пуризам}

Копитар је био против мешања језика и био је пурист у погледу употребе страних речи у народном језику.
Вук је био одлучно против употребе славенизама и кованица. Сматрао је да је неопходно радикално очистити књижевнојезички узус од неаутентичних елемената и стално водити бригу о чистоти језика, односно борити се против његовог кварења.

Копитар-Вуков реформни пројекат. - Један од закључака који произилази из горње табеле јесте да је Копитарова концепција садржавала кључна полазишта Вукове реформе ${ }^{4}$ р радикално понарођивање (србизирање) књижевног језика; инсистирање на аутентичном говорном језику, немешању језика и дијалеката и одговарајућем пуризму; популизам (уп. непокварени језик села као решење за књижевни језик); почетни дијалекатски плурализам и органску (а не вештачку) дијалекатску унификацију; инсистирање на верном транспоновању народног језика у књижевност, са ускраћивањем језичким стручњацима или ученим друштвима било какве слободе селекције или модификације (тј. искључивање артифицијалности у књижевном језику и одузимање аутономије књижевном

${ }^{4}$ А. Белић (1948 [1910]; 198) пише:

Све идеје које је Вук износио о потреби увођења народног језика биле су Копитарове или извођење из његових идеја. Реформа Вукова дело је њих двојице у којем је и прву иницијативу, и основну идеју, и цео план дао - Копитар.

${ }^{5}$ О Копитаровим погледима на дијалекте и књижевни језик в. Ленчек 1971 и 1983: 127-131. 
језику у односу на народни); почетно игнорисање проблема елаборације новог књижевног језика као једног од кључних проблема; захтев за рационалном азбуком по правилу „пиши као што говориш” и - по Јагићу - и за фонолошким правописом; инсистирање на фолклорном корпусу и преводу Светог писма; комбиновање књижевнојезичке реформе са потребом да се страни филолози упознају са српским језиком, а и они и „Европа” са народном књижевношћу на том језику. Зато се програм који је заступао Вук може слободно окарактерисати као Копитар-Вуков реформни пројекат.

Копитар и неки проблематични аспекти почетног Вуковог реформног програма. - Везивање Вуковог програма за Копитарову концепцију књижевног језика истовремено значи да је и оно што у Вуковом почетном програму делује као идеолошки радикализам, као популизам, као једностраност у оцени текуће ситуације и напора тадашње војвођанске интелигенције да литераризују српски књижевни језик, као волунтаризам и утопизам кад је реч о редукцији књижевног језика на народни - не потиче само од Вука него и од Копитара. А од Копитарових погледа потичу и проблеми који су потенцијално стајали пред стандардизацијом српског књижевног језика (али које је Вук успешно решио, в. т. 4). И најзад, Копитар је, својом делимитацијом „српског” језика, утицао на контроверзне међунационалне аспекте Вукове реформе. ${ }^{6}$

Идеолошки карактер Вуковог ребормног програма. - Иако реформни програм који је Вук изнео у својим раним списима (нарочито у предговору Српском рјечнику из 1818. год.) веома много дугује Копитару у погледу свог идејног садржаја, ипак је то у два важна правца Вуков програм. С једне стране, Вук је Копитарове ставове конкретизовао, везујући их за српске прилике на начин који је одражавао не само Вукове личне ставове него и менталитет једног представника балканског Српства и патријархалне културе. А с друге стране, Вук је Копитаровим ставовима дао битну нови димензију - изнео их је као идеолошки реформни програм. Наиме, Вук је један стручни проблем, данашњом терминологијом речено - проблем језичког планирања, претворио у идеолошко питање: проблематизовао је и драматизовао текућу књижевнојезичку ситуацију, напао најактуелније од дотад понуђених решења ${ }^{7}$ и дезавуисао целокупну интелигенцију као језички некомпетентну; а с друге стране, покушао је да наметне књижевнојезичко опредељење које се може означити као радикално посрбљавање (србизација) језика, алфабета и правописа,

\footnotetext{
6 Више о Копитаровом утицају на Вука в. у Ивић 1981.

7 Видаковићево, а оно је, бар у почетној фази, било и доситејевско.
} 
праћено захтевом да сваки писац учи народни језик, стално води бригу о свом језику и буде конзистентан у свом правописном узусу.

\section{3. Реализација Вукове реформе}

Структура Вукове реборме. - Основу Вукове реформе чине Копитар-Вуков пројекат реформисања књижевног језика и правописа код Срба. Тај пројекат чине следеће компоненте: (1) реформисање писане форме, која обухвата писмо и графију и избор базичног правописног принципа (фонемско или морфемско представљање речи); (2) опис народног језика, који обухвата опис језичких система и лексичког (и фразеолошког) фонда; (3) егземплификација народног језика, тј. стварање корпуса фолклорних текстова; (4) егзамплификација Вуковог узуса, тј. стварање корпуса оригиналних и преводних Вукових текстова; (5) реформисање текућег књижевног израза и развијање језичке културе; (6) проширивање знања релевантних за књижевни језик, пре свега о дијалектима, затим о односу српског и рускословенског („славенског”) језика и о српскословенском језику.

Касније је Вук морао да се позабави и неким у почетку занемареним аспектима језичке реформе - селекцијом и кодификацијом језичких норми и лексичком елаборацијом, као и трансконфесионалном односно транскултурном језичком унификацијом са Хрватима, код којих се јавио илирски покрет.

Компоненте Вукове реформе биће приказане у следеће две табеле, и то најпре Копитар-Вуков пројекат, а онда додатне компоненте. Што се тиче ефеката појединих компоненти на стандардизацију књижевног језика, о томе ће бити речи у следећој тачки.

Копитар-Вуков реформни пројекат и негова реализација. - У следећој табели су укратко изложене (1) природа и сврха компоненти овог дела Вукове реформе и (2) напомене о њиховој реализацији.

8 Подаци изнети у овом и следећем одељку су већ познати из досадашње литературе о Вуковој реформи. Оно што се овде жели јесте да се артикулише структура Вукове реформе и та артикулација сажето објасни и прокоментарише.

9 Дијаграм који приказује структуру Вукове реформе и списак одговарајућих тестова дат је на крају рада. 


\section{Компоненте Копитар-Вуковог пројекта вернакуларизације књижевног језика и правописа код Срба}

\section{Реформисање писане форме књижевног језика}

Ова компонента је обухватила реформу (1) ћирилице (и њене графије) и (2) базичног правописног принципа. Пошто се ради о писаном језику, ово је једна од кључних компоненти реформе. Била је потребна и због нерешеног текућег правописног питања, које се више преокупирало писце, и ради успешне реализације осталих компоненти.
Писана форма је регулисана по правилу „пиши као што говориш, а читај као што је написано... што је сасвим у духу Копитарове концепције, али свакако и у складу с Вуковим личним приступом. На тај начин је добијена писана форма која је, с малим одступањима, фонемска транскрипиија народног говора. Другим речима, добијена је рационална и потпуно понарођена одн. посрбљена азбука (и графија) и фонемски, а не морфемски правопис.

\section{Опис народног језика}

Ова компонента је подразумевала објављивање (1) граматике и (2) речника народног језика. И једно и друго је било потребно да би се писци упознали са правим народним језиком и да би се створила нова узуелна норма. Али су речник и граматика (за којима се и иначе све више осећала потреба у круговима интелигенције) били нужни и за респектабилност новог књижевног језика, а подизали су и углед Вуку. Уз то, били су средство презентирања српског језика странцима, пре свега страним филолозима.

\section{Егземплификација народног језика (формирање фолклорног корпуса)}

И за језичко „преваспитавање” писаца, и за популарисање народног језика, и за респектабилност новог књижевног језика, и за презентирања српског језика и српског фолклора „Европи” било је неопходно објављивање народних умотворина, а пре свега народних песама, дакле стварање фолклорног корпуса.
Што се тиче описа народног језика, ту пре свега пада у очи да се граматички опис (1814) јавља пре лексикографског (1818), сигурно не само зато што је граматика била потребнија за реформу и него и што ју је било лакше написати. Могло би се додати и то да је лексикографски опис језика настављен (уп. Српски рјечник из 1852), а да је касније нову граматику написао Даничић (који је, истина, радио и на овом рјечнику). Од традиционалних делова граматике недостаје синтакса, која је била и мање неопходна и много тежа за израду.

Вук је скупљао и издавао разне народне умотворине, и то највише народне песме. То је у складу са стварном вредношћу овог вида фолклорне књижевности и са потребом презентирања српске народне културе европској јавности, која је нарочито ценила народну поезију, али и са потребом да се створи један не само језички него и књижевно ауторитативни корпус. 


\begin{tabular}{|l|}
\hline \multicolumn{2}{|c|}{ Егземплификација Вуковог узуса } \\
\hline Вук је тражио од сваког писца да пише чи- \\
стим народним језиком и да има „постојана \\
правила” у писању. Да би се то остварило, \\
требало је пружити и лични пример и дати \\
обрасце разних врста текстова (функцио- \\
налних стилова). А за кредибилитет новог \\
књижевног језика кључни текст је био пре- \\
вод Светог писма.
\end{tabular}

\section{Реформисање текућег књижевног израза}

Цео Копитар-Вуков пројекат је направљен ради реформисања текућег стања књижевног језика и правописа код Срба (а уз то и презентирања српског језика и фолклора европској научној јавности). Другим речима, радило се о томе да се писци приволе да измене и стандардизују свој језички и правописни узус односно да усвоје чист народни језик и одговарајући правопис и да их конзистентно употребљавају. Зато је било потребно указивање на неодрживост и штетност текућег стања и пропагирање Вуковог (и Копитаровог) решења. Поред ове идеолошке активности, била је потребна и језичка критика и поука, ради чишћења (пурификације) књижевнојезичког израза од славеносербизама (славенизама, русизама, лоших кованица, хибридних словенско-српских речи и граматичких облика, страних обрта, лоших правописних решења итд.), ради аутентификације и ради стандардизације текућег књижевног израза.
У својим текстовима, оригиналним и преводним, Вук је егземплификовао узорну редакцију аутентичног српског књижевног језика (како га је он конципирао), пре свега у његовој ијекавској варијанти, али у једном периоду свог стварања и у екавској. Све је то имало за декларативни циљ представљање разних говора, одн. дијелакта. Што се тиче Светог писма, Вук је превео само Нови завет.
За књижевни успех Вукове реформе један од битних момената је било добијање разних битака на идеолошком плану. На тај начин је Вук успео да интелигенцији и широј јавности наметне негативну перцепцију текућег књижевнојезичког и правописног стања, да кривицу за то припише (до)тадашњим писцима, да дискредитује противнике и њихове ставове и наметне сопствено решење као једино прихватљиво и за све обавезно. То су најважнију улогу одиграле књижевне и језичке критике и одговори на нападе идеолошких противника. У тим текстовима налази се и највећи део „језичких поука" (остатак је у граматикама и реченицама и појединим другим списима).

\section{Проширивање знања релевантних за књижевни језик}

Реализација Копитар-Вуковог пројекта подразумевала је и стално проширивање знања о народном језику, али и о односу српског језика са рускословенским, старословенским и српскословенским. Све ово је било и у функцији Вукове реформе, али и филолошке афирмације српског језика.
Почетно недовољно познавање - или упрошћена интерпретација - дијалекатске диверсификованости (редуковање разлика скоро само на рефлексе јата) један је од одлучујућих фактора за стандардизацију (в. т. 4). Но касније проширивање знања о дијалектима довело је до неких измена у Вуковом узусу и наметнуло селекцију аутентичних језичких појединости и прокламовање принципа „опћене правилности”. А правилно схватање односа српског, рускословенског и српскословенског језика било је важно и на идеолошком и на практичном плану. 
Дакле, у неким компонентама реформе Вук је морао да унеколико модификује оригинални пројекат: постепено је одступио од потпуно органске природе сопственог узуса (писање гласа $x$, сужавање обима ијекавског јотовања и др.), а уз то је привремено употребљавао екавску варијанту. Сем тога, неке делове пројекта Вук није успео да реализује (опис синтаксе, превод Старог завета).

Додатне компоненте Вукове реформе - Почетни Копитар-Вуков реформни пројекат морао је бити проширен у неколико праваца, а истовремено и идеолошки унеколико модификован кад је реч о селекцији детаља књижевнојезичке норме, кодификацији и елаборацији. Ови аспекти Вукове реформе укратко су приказани у следећој табели.

Додатне компоненте Вукове реформе

\begin{tabular}{|c|c|}
\hline ПРИРОДА И СВРХА & РЕАЛИЗАЦИЈА \\
\hline \multicolumn{2}{|c|}{ Селекција и кодификација } \\
\hline $\begin{array}{l}\text { Стварање новог књижевног језика захтевало } \\
\text { је не само описивање народног језика него и } \\
\text { филтрирање особина народног говора однос- } \\
\text { но налажење најбољег решења у појединим } \\
\text { случајевима где се дијалекти разилазе, као и } \\
\text { обавезивање свих писмених људи да се придр- } \\
\text { жавају изабраног стандарда. }\end{array}$ & $\begin{array}{l}\text { По Копитаревој, а онда и Копитар-Вуковој кон- } \\
\text { цепцији стварање јединствене норме било је } \\
\text { одложено за касније фазе органске дијалекатске } \\
\text { унификације, тј. није спадало у почетни проје- } \\
\text { кат; а посао језичког стручњака је био само да } \\
\text { опише народни језик. Међутим, касније је Вук } \\
\text { почео да признаје потребу избора, а не само де- } \\
\text { скрипције језичких факата и сам почео да врши } \\
\text { избор онога што из дијелаката треба да уђе у } \\
\text { књижевни језик (екавски рефлекси јата, писање } \\
\text { x, резултати јекавског јотовања и др.) }{ }^{10} \text {; а увео } \\
\text { је и принцип „опћене правилности”. Тиме је Вук } \\
\text { извршио један идеолошки битан заокрет, који } \\
\text { је његовој реформи додао две неопходне ком- } \\
\text { поненте - селекцију и кодификацију (ово друго } \\
\text { само на идеолошком плану, јер Вук није пред- } \\
\text { стављао званични ауторитет). }\end{array}$ \\
\hline \multicolumn{2}{|c|}{ Лексичка елаборација } \\
\hline
\end{tabular}

10 У ствари, селекција је започета одмах; како је показао П. Ивић (1966: 176$182)$ „почетак Вуковог одабирања особина достојних да уђу у књижевни језик” везан је већ за Вукову примену тршићког говора у писаним текстовима. 
Увођење говорног језика у књижевност отворило је проблем његовог покњижевљавања а пре свега комплексни и стално присутни проблем лексичке елаборације, која треба да задовољи све веће и веће потребе за новим речима и изразима, у све разуђенијим функционалним стиловима. А додатни проблем је било и питање селекције и кодификације дијалекатске одн. регионалне лексике.
За присталице доситејевског књижевнојезичког опредељења, питање литераризације било је централно питање усавршавања новог (доситејевског) књижевног језика. Вук је, међутим, ове проблеме потиснуо у позадину. То је сигурно утицало на литераризованост каснијег српског књижевног језика, али је упростило Вуков задатак је га је поштедело једног посла који би му сигурно наметнуо разне не само практичне него и идеолошке проблеме и за који он није био најбоље припремљен. Ипак, промена става о односу народног и књижевног језика односно ставова о селекцији и кодификацији, као и проблеми на које је наишао преводећи Нови завет, одразили су се и на Вукове ставове у вези са лексичком елаборацијом: Вук је признао постојање овог проблема, ублажио свој пуристички став према рускословенском језику и показао, теоријски и практично, на који начин треба попуњавати лексички фонд. С друге стране, и даље је инсистирао да се при лексичкој елаборацији колико је год могуће чува аутентичности српског књижевног језика и одупирао се терминолошком раду који су организовали по његовом мишљењу за тај рад некомпетентни чланови Друштва српске словесности. Што се тиче регионализма, Вук је тај проблем оставио за неко касније време, када дијалекатска лексика буде боље позната.

Трансконфесионална и транскултурна језичка унификација са Хрватима

Принцип коекстензивности новог српског књижевног језика и народног српскохрватског („српског”) језика, или бар његових штокавских дијелеката, неминовно је водио потреби унификације са илирским књижевним језиком, наравно на вуковским основама. Наравно, пожељно је било имати и заједнички алфабет и правопис.
Вукови идеолошки ставови у погледу ових питања - при чему не треба губити из вида да су они добрим делом одговарали ставовима тадашње науке - морали су се суочити са реалном ситуацијом на плану националних, културних и књижевнојезичких српско-хрватских односа. У сваком случају, начин на који је Вук желео да реши ова питања додао је унутарсрпским контроверзама око његове реформе и хрватско-српске контроверзе (а касније и унутархватске).

\section{4. Вуков приступ стандардизацији књижевног језика}

Криптостандардизација. - Један од битних резултата вукове реформе јесте стварање модерног српског језичког стандарда, што се и могло очекивати од реформе која је добрим делом била мотивисана не- 
сређеним језичким приликама у српској књижевнојезичкој пракси. Но начин на који се дошло до тог стандарда сасвим је специфичан, пре свега због два већ поменута принципа Копитар-Вуковог пројекта: органске унификације дијалеката и ограничавања граматичарског и лексикографског рада на дескрпцију аутентичног народног језика. Међутим, иако је Вук дуго времена заступао ове принципе, његова реформа је од почетка пошла нешто другачијим путем, који је недекларисано, али директно водио успостављању јединственог књижевнојезичког стандарда.

Вук је, наиме, захтевао да сваки писац пише својим дијалектом, а уз то је као најаутентичније дијалекте означио оне јужно од Саве и Дунава. То је, с једне стране, значило да је Вуков завичајни говор (тршићки) легитимна основица за један од валидних националних стандарда ${ }^{11}$; а с друге стране - да се Вук могао у писаним текстовима служити својим идиолектом, тј. једним мање-више стандардизованим језичким варијететом. Другим речима, са гледишта Копитар-Вуковог пројекта, оно што је Вук писао била је једна верзија (варијанта) аутентичног српског књижевног језика на његовом почетном стадијуму. А пошто су се и обе граматике и речник из 1818. поглавито базирали на Вуковом завичајном говору односно његовом идиолекту ${ }^{12}$, и они су, без обзира што су декларативно публиковани у функцији дескрипције народног језика, фактички конкретизовали Вукову верзију новог књижевног језика. При том је Вукова репутација најбољег зналца правог народног језика обезбеђивала ауторитет његовом опису и његовој егземплификацији народног језика. А за успех Вукове реформе посебно је било важно што су и народне песме које је Вук објављивао такође егземплификовале његов тип језика.

Дакле, Вукова идиолекатска верзија је у принципу представљала једну од реализација радикалне вернакуларизације односно аутентификације која је била главни циљ Копитар-Вуковог пројекта. Али тиме није принципски решен проблем потенцијалног плурализма оваквих аутентификација. Наиме, примена принципа да сваки писац пише својим дијалектом могла је да доведе до стварања различитих верзија аутентичног српског књижевног језика. Другим речима, да би се добио национални стандард,

11 Ово је, наравно, упрошћена слика. Наиме, Вук је одмах морао да елаборира свој завичајни говор да би могао да пише стручне текстове, тј. да пише о предметима - и по стандардима - које је наметала тадашња урбана европска цивилизација. С друге стране, Вук није унео у свој писани израз све црте тршићког говора (в. Ивић 1966: 176-182).

12 За Српски рјечник из 1818. П. Ивић (1966: 79) каже:

... Вуково прво издање [Српског рјечника] је у основи речник говора једног човека. 
требало је принципски решити питање дијалекатске унификације, тачније унификације потенцијалних верзија српског књижевног језика заснованих на различитим дијалектима. Вуково решење овог проблема имало је две компоненте. Једна од њих би се могла означити као редуктивна концепиија дијалекатских разлика: Вук је, наиме, у почетку своје реформе прогласио да се дијалекти разликују само по рефлексима јата (и неким ситним додатним детаљима). Самим тим, његова верзија је имплицитно постала општи стандард, сем у погледу решења рефлекса јата. Друга компонента би се могла означити као кюижевнојезички плурализам реблекса јата (или, евентуално, као плурализам јатовских ликова књижевног језика). У складу са принципом дијалекатског плурализма, Вук је све рефлексе јата означио као аутентичне, дакле прихватљиве за књижевни језик и међусобно равноправне. Тако је његова верзија имплицитно постала ијекавски лик српског књижевнојезичког стандарда. А каснији Вукови екавски текстови су практично представљали селекцију и фиксирање екавског лика књижевног језика, чиме је и ова друга, у тадашњој српској књижевној продукцији далеко распрострањенија, варијанта књижевног језика добила одговарајућу имплицитну норму. Дакле, својом редуктивном концепцијом дијалекатских разлика Вук је, бар на програмском плану, разрешио проблем унификације, уз један, истина значајан, уступак дијалекатској диверсификованости; а у исто време остао је доследан Копитаровом принципу почетног дијалекатског плурализма као оптималног начина за формирање књижевног језика на народној основи.

Тако је Вук, опредељујући се за сопствени дијалекат (како је препоручивао и другима) и бавећи се дескрипцијом и егземплификацијом народног језика, а не прескрипцијом, фактички створио имплицитни књижевнојезички стандард. Зато би се тај његов поступак могао назвати криптостандардизацијом српског књижевног језика. Но треба додати да Вук није до краја остао на почетним позицијама, него је, дорађујући свој стандард, вршио свесну селекцију међу опцијама које су му пружали дијалекти (избор екавског лика, писање гласа $x$, реконструкција ијекавског лика и др.). А прокламовање принципа „опћене правилности” представљало је не само кодификацију изабраног стандарда и него и имплицитно прихватање (1) селекције као једног од неопходних поступака књижевнојезичке стандардизације и култивације и (2) тексичке елаборације као нужне за богаћење језика. Тако је Вук - најпре само прагматички, а онда и декларативно - умногоме усагласио свој приступ вернакуларизацији и стандардизацији са књижевнојезичком реалношћу, што се може тумачити и као модификација и превазилажење почетног Копитар-Вуковог пројекта и као извесна дезидологизација Вуковог реформног програма. 
Фактори успеха Вуковог припступа. - Што се тиче стандардизације, кључне практичне слабости Копитаровог приступа биле су почетно толерисање дијалекатске нехомогености и искључивање нормализаторске иницијативе. Вук је, видели смо, неутралисао и једно и друго на један једноставан начин: тиме што је у почетку своје реформе третирао народни језик (са изузетком рефлекса јата и неких ситних детаља) као - да се послужимо терминологијом Д. Брозовића (1970: 12) - конкретни идиом. Дакле, норма је била ту - у (аутентичном) народном говору, само ју је требало показати, да би они који не говоре чистим народним језиком, односно који га не знају добро, могли да је науче и употребљавају у писању. Према томе, било је довољно да Вук пише својим непоквареним народним говором и да га верно опише. Овакав редукционизам је представљао нешто што се могло назвати онтолошким схватањем норме ${ }^{13}$, насупрот схватању норме као креиране свесном селекцијом. Касније је Вук унеколико одступио од ове „реалистичке” концепције норме и приближио „номиналистичкој”, јер је доступио граматичарима (и писцима) да у неким случајевима одаберу оно што је боље односно да одбаце оно што није аутентично. То истовремено значи да је у каснијој фази своје реформе Вук прихватио бар известан степен аутономности књижевног језика у односу на народни.

Поред наведеног начина разрешавања проблема унификције књижевног језика, успех Вуковог приступа стандардизацији условљен је и разним другим факторима, међу којима су и следећи: реалтивна уједначеност новоштокавских дијалеката и Вукова почетна недовољна обавештеност о дијалекатским разликама; велика уједначност језика народних песама и других умотворина; чињеница да је Вуков завичајни говор био тршићки, а не, нпр., неки од говора призренско-тимочког дијалек$\mathrm{Ta}^{14}$; Вукова језичка и лингвистичка компетентност, која се испољавала и у егземплификацији и у дескрипцији народног језика, чему треба додати и заслужени ауторитет најбољег, чак јединог правог зналца аутентичног народног говора; ослањање на сопствени идиолект, који је био инхерентно стандардизован јер је представљао индивидуални конкретни идиом и био пример једног конкретног органског идиома какав је локални говор; чињеница да је Вук био једини, или једини ауторитативни, заступник радикалне вернакуларизације књижевног израза, јер да је било више таквих људи, могло би се десити да Вуков стандард буде само један од конку-

13 Уп. и шта пише Копитар 1813. год. (у вези са језиком у Новинама сербским): Изговор да још не постоји српска граматика и да, дакле, још не постоје чврста правила писања, никако не може да се прихвати као оправдање за овакво не простиво непоштовање лепог језика: ... она [=граматика] ипак постоји у говору свих живих Срба... (Копитар 1984: 146-147).

14 А да је му је говор био екавски, Вуку би било још лакше. 
рентних стандарда; а сигурно му је наруку ишло и то што у почетку није имао других сарадника сем Копитара, јер би увек постојала опасност од језичког дисидентства, односно одбацивања Вуковог и предлагања „правог” решења од стране неког бившег вуковца.

Стандардизащиони поступщи. - У својој „криптостандардизацији” Вук је применио следеће конкретне поступке:

1) Експлицитна конкретизација норме:

a) систематске конкретизације, тј. опис (а фактички прескрипција) језичких система;

б) лексичка конкретизација, тј. инвентарисање, квалификовање (нарочито кад је реч о турцизмима) и објашњење лексике и - у много мањој мери - фразеологије, коју пружа Српски рјечник;

в) „језичке поуке”, тј. разни ставови, пре свега у оквиру језичке критике, који су, у свом проскриптивном аспекту, садржавали критику и осуду употребљених језичких средстава, а у прескриптивном - препоручивали или захтевали употребу одговарајућих аутентичних средстава.

2) Имплицитна одн. егземплификациона кодификација, која се састоји у стварању узорног (ауторитативног, канонског) корпуса текстова који илуструју употребу и даје обрасце књижевног језика који се нормира, а тиме имплицитно спецификује и сам језик.

Сви ови поступци имају прескриптивни нормативни значај, јер конкретизују књижевни језик, а многи су и проскриптивни, јер искључују из тог језика потенцијалне појаве које су се јављале у књижевнојезичкој пракси или постојале у дијалектима, а нису биле прихватљиве за књижевни језик.

Што се тиче текстова којима су ови поступци реализовани, они обухватају пре свега граматике и речнике, затим малобројне студије о појединим питањима и све оно што се може подвести под појам језичким поука; а други тип нормативно релевантних текстова представљају ауторитативни језички корпуси (Вуков и фолклорни).

Табеларни приказ Вукове стандардизаиије. - Кад се узме у обзир број конкретних норми које треба фиксирати при стварању књижевног језика и разноврсност поступака који се могу или морају применити, разумљиво је да процес стандардизације представља веома комплексну појаву. Тако је било и у случају Вукове реформе. То илуструје следећа табела, у којој је приказана Вукова стандардизација српског књижевног језика у оквиру седам типова норми ${ }^{15}$.

${ }_{15}$ Овоме треба додати и Вукове ставове о дијалектима, регионализмима, лексичкој елаборацији и, наравно, о „опћеној правилности”. 
Вуков приступ вернакуларизацији и стандардизацији кюижевног језика...

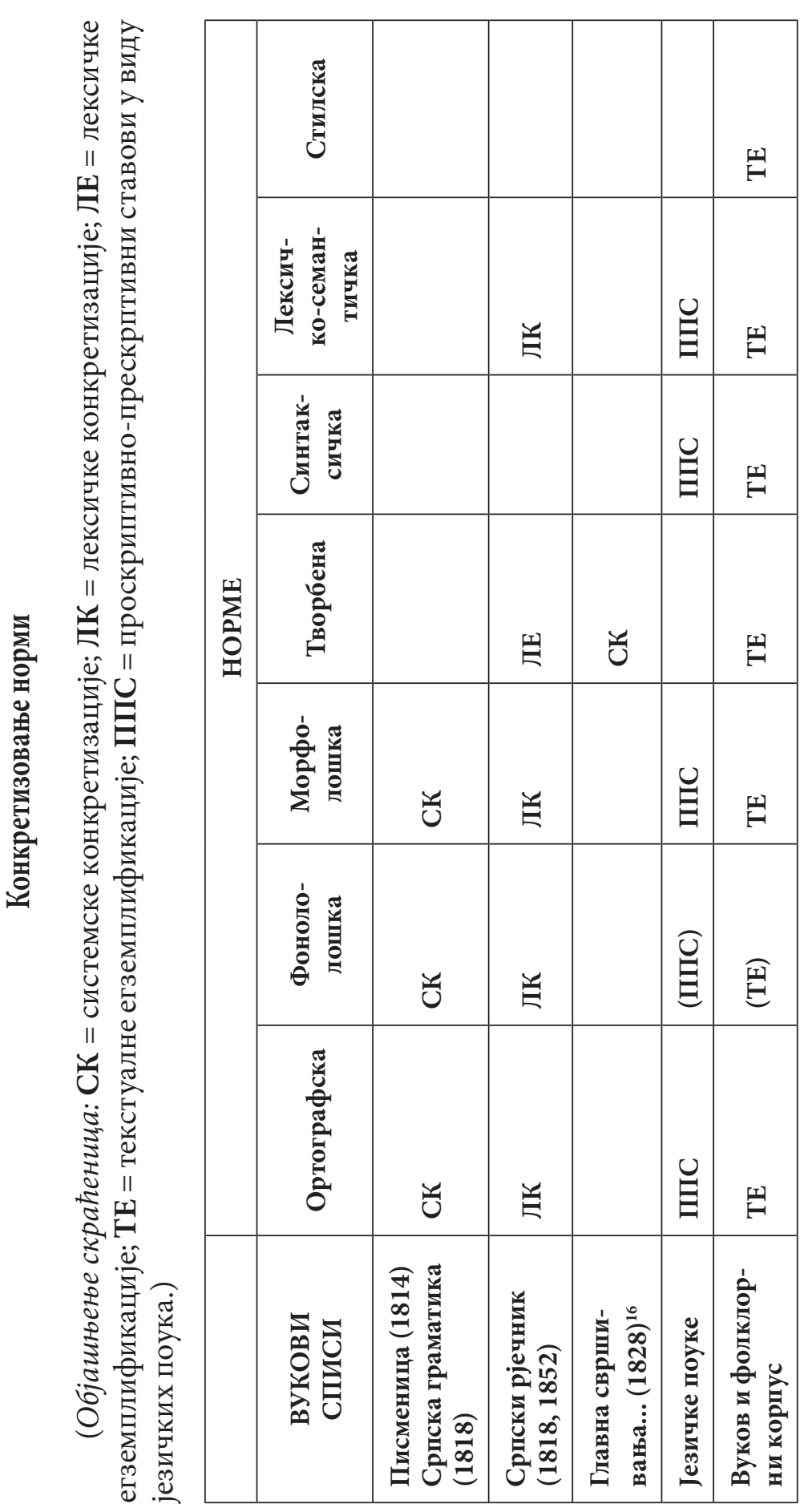

$\hat{\mathscr{\nu}}$

$\stackrel{\infty}{\infty}$

$\infty$

产

จ

c

$\underset{1}{3}$

ఏँ

?

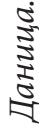

盗通

需

茞

空

\&

.

岀

ิㅡㅂ

䒕

율

5

5

范

๑

5

政

U

ติ

ปิ

ช

常

品

見类

ติ

芆

范

ํํำ

긱

$\because \stackrel{\circ}{\mathrm{B}}$ 
Коментар табеле. - Стандардизациони поступци треба да чине један функционални систем којим се спецификује шта спада (прескрипција) и шта не спада (проскрипција) у књижевни језик. Но конкретна природа таквог система условљена је многим чиниоцима, те свака књижевнојезичка стандардизација, укључујући и Вукову, представља самосвојну појаву. У Вуковом случају, то се најбоље види по томе што су норме конкретизоване на разне начине и у неједнакој мери, а и у различито време. (На пример, ако се упореде морфолошка и синтаксичка норма, онда би се за другу могло рећи да је на експлицитном плану остала без адекватне конкретизације). Наравно, многе разлике које показује горња табела могу се објаснити и чињеницом да свака норма има својствене начине за конкретизовање; да није потребно сваку норму експлицирати у истој мери и у исто време; да се неке норме могу и само егземплификовати; да није сваку норму подједнако лако експлицирати; да поједине норме, пре свега лексичка, нису потпуно стандардизоване ${ }^{17}$. Али је ипак садржај ове табеле добрим делом одраз Копитар-Вуковог приступа и Вукових могућности, као и околности у којима је он делао ${ }^{18}$.

Једна ствар коју треба истаћи - нарочито у светлу данашњих дискусија о томе да ли нам је књижевни језик нормиран или не - јесте важност егземплификације, која може да компензира одсуство експлицитне кодификације и без које би било тешко замислити имплементацију новог књижевног језика ${ }^{19}$. При том корпус не мора бити канонски до детаља: довољно је сетити се да у народним умотворинама има појединости које

${ }_{17}$ Нпр. Јагић (1948: 552) констатује 1901. год.: Лексикално није српскохрватски књижевни језик још ни издалека тако учвршћен као граматички. Он то не може, а засад још и не треба да буде. А затим објашњава своје мишљење.

18 Што се тиче Вукових схватања о релативној важности појединих аспеката стандардизације, њих показује следећи цитат:

..да садашюи наш спаситељ а) мора знати: склағьати сва имена и мјестоименија; б) да мора знати спрезати глаголе; в) да мора знати по Српском синтаксису из ријечи разговоре састављати...; г) да мора имати тврду и постојану једнакост у писању ријечи (Караџић 1894-1896 [1820], књ. II: 99).

19 Један пример учења језика не само из Вукове граматике него и из народних песама пружа следећа изјава Јоксима Новића:

Прва књига Српства сасвим је готова. Ја сам се трудио и годио, колико сам жешће и боље могао, да буде ваљана; јесам ли погодио и удесио, то ћете ви, осим свију Срба, најбоље познати, јер сте ми ви огледало, па сам се по вама владао; зато вас молим, штогођ нађете и видите да је неприлично мисли и језику, то избаците, и штогођ вам по вољи или у ћуди не буде, да истришете; јер сам увјерен да ви Српски и мислите и чините, а исто сам рад и сам. Не ћете вјеровати, како сам се намучио око ове књиге, учећи 
нису биле део Вукове норме, а да је и сам Вуков узус претрпео извесне измене, што није касније сметало да се и фолклорни и цео Вуков корпус третирају као класични корпус и употребљавају као један од извора за нормирање и код Срба и код Хрвата. ${ }^{20}$

\section{Главни текстови који се тичу наведених компоненти}

(Знаком = указује се на промену решења.)

1. Писменица сербскога језика (Беч, 1814), Српска граматика (уз Српски рјечник, Беч, 1818).

2. Српска граматика (уз Српски рјечник, Беч, 1818).

3. Писменица сербскога језика (Беч, 1814), Српска граматика (уз Српски рјечник, Беч, 1818) (и Српски рјечник, Беч, 1818. и Српски рјечник, Беч, 1852).

4. Писменица сербскога језика (Беч, 1814), Српска граматика (уз Српски рјечник, Беч, 1818).

5. Српски рјечник (Беч, 1818) и Српски рјечник (Беч, 1852).

6. Мала простонародња славено-сербска пјеснарица (Беч, 1814), Народна србска пјеснарица (Беч, 1815), Народне српске пјесме I-III (Лајпциг, 1823), IV (Беч, 1833), Српске народне пјесме I-IV (Беч, 1841, 1845, 1846, 1862).

7. Народне српске приповијетке (Беч, 1821), Српске народне приповијетке (Беч, 1853), Народне српске пословице (Цетиње, 1836), Српске народне пословице (Беч, 1849).

8. Вукови текстови писани „ерцеговачким нарјечјем” („херцеговачким говором јужног нарјечја”) = писани са $x$, према говору „нај јужнијих крајева народа нашега" (Народне српске пословице, Цетиње, 1836, и даљи текстови) = писани „дубровачким говором” (Одговор на Ситнице језикословне, Беч, 1839, и даљи текстови).

9. Вукови текстови писани „источним нарјечјем” 1828-1834. (Милош Обреновић..., Будим, 1828, и др.).

изновце и Граматику вашу и из вашије пјесмарица Синтаксис (Писмо Јоксима Новића Вуку, 1837, in Караџић 1993: 54; а в. и стр. 115-116).

(Овај цитат сведочи и о ауторитету Вука као језичког зналца и арбитра.)

20 Још један узгредни закључак би могао бити постојање дискрепанција између експлицитне кодификоване норме и књижевнојезичке праксе (узуса). То лепо показује кодификација икавске норме, која је, што се примене тиче, остала само потенцијална, могло би се рећи празна, норма. 
10. Нови завјет господа нашега Исуса Христа (Беч, 1847) (и Огледи Светога писма на српском језику, Лајпциг, 1824).

11. Рецензија Видаковићевог Љубомира у Јелисијуму (Новине сербске, Беч, 1817), Предговор Српском рјечнику (Беч, 1818), Примјечанија на преводе г. Томе Љубибратића (Новине сербске, Беч, 1820), Неколико ријечи мојим овогодишњим рецензентима (Новине сербске, Беч, 1821), Одговор на Ситнице језикословне г. Ј. Хаџића = М. Светића (Беч, 1839), Вуков одговор на Утук г. М. Светића (Беч, 1843), Вука Стеф. Караџића и Саве Текелије писма високопросвештеном господину Платону Атанацковићу ... о српском правопису са особитијем додацима о српском језику (Беч, 1845), [Одговор на] Утуку IIIјезикословни од М. Светића (Сербски народни лист, Пешта, 1847).

12. Рецензије, критике и полемике почев од Рецензије Видаковићевог Усамљеног јуноше (Новине сербске, Беч, 1815).

13. Писменица сербскога језика (Беч, 1814), Рецензија Видаковићевог Љубомира у Јелисијуму (Новине сербске, Беч, 1817), Српска граматика (уз Српски рјечник, Беч, 1818), Предговор Народним српским пословицама (Цетиње, 1836), Одговор на Ситнице језикословне г. Ј. Хаџића = М. Светића (Беч, 1839).

14. Писмо Димитрију Фрушићу (Новине сербске, Беч, 1821), Главне разлике између данашњега славенскога и српског језика (Даница за 1826 , Беч, 1825), Примјери српско-славенскога језика (Беч, 1857).

15. Вука Стеф. Караџића и Саве Текелије писма високопреосвештеном господину Платону Атанасковићу ... о српском правопису са особитијем додацима о српском језику (Беч, 1845).

16. Главна свршивања сушествителни и прилагателни имена у српском језику (Даница за 1828, Беч, 1827).

17-21. Вука Стеф. Караџића и Саве Текелије писма високопреосвештеном господину Платону Атанацковићу ... о српском правопису са особитијем додацима о српском језику (Беч 1845), Предговор Новом завјету... (Беч, 1847).

22. Glavna pravila za južno narječje (Narodne Novine, Zagreb, 1850) (i Književni dogovor, Narodne Novine, Zagreb, 1850).

23. Odgovor Vuka Stef. Karadžića [Vjekoslavu Bubukiću] (Kolo, 3aгреб, 1847), Вука Стеф. Караџића Посланица Анту Кузманићу у Задар (Slavische bibliothek I, Беч, 1851).

24. Срби сви и свуда (у В. С. К. Ковчежић за историју, језик и обичаје Срба сва три закона, Беч, 1849), Срби и Хрвати (Видовдан, Београд, 1861). 


\section{ЦИТИРАНА ЛИТЕРАТУРА}

Белић, 1948: А. Белић, Вукова борба за народни и книжевни језик, Београд: Просвета.

Брозовић, 1970: Dalibor Brozović, Standardni jezik, Zagreb. Matica hrvatska.

Ивић, 1966: Павле Ивић, „О Вуковом Рјечнику из 1818. године” in: Вук Караџић, Српски рјечник (1818) (= Сабрана дела Вука Карачића, књ. II), Београд: Просвета.

Ивић, 1981: Pavle Ivić, „Kopitarov uticaj na Vuka Karadžića i razvoj Vukovih shvatanja”, Slavistička revija, 29/2, str. 149-158.

Јагић, 1948: Vatroslav Jagić, Izabrani kraći spisi (uredio i članke sa stranih jezika preveo Mihovil Kombol), Zagreb: Matica hrvatska.

Караџић, 1894-1896: Вук. Стеф. Караџић, Скупљени граматички и полемички списи, I-III, Београд: државно издање.

Караџић, 1993: Вук Караџић, Преписка, књ. VI (= Сабрана дела вука Карачића, књ. XXV), Београд: Просвета.

Копитар, 1971: Rado, L. Lencek, „The Enlightenment's Interest in languages and the National Revival of the South Slavs", Canadian Review of Studies in Nationalism, 10

Погачник, 1977: Jože Pogačnik, Jernej Kopitar, Ljubljana: Partizanska knjiga.

Поповић, 1988: Љубомир Поповић, „Вуков програм књижевнојезичке реформе (у поређењу с Доситејевим)" in: Научни састанак слависта у Вукове дане, 17/1, стр. 265-278.

Стојановић, 1924: Љубомир Стојановић, Живот и рад Вука Стефб. Караџића, Београд.

* Рад је претходно објављен у зборнику Научни састанак слависта у Вукове дане, 25/2, 451-472. 